\title{
SPECIES OF BRANCHIOBDELLIDAE (ANNELIDA) ON FRESHWATER CRAYFISH IN SOUTH TYROL (NORTHERN ITALY).
}

\author{
B. OBERKOFLER (1), F. QUAGLIO (1), L. FÜREDER (2), M.L. FIORAVANTI (3), \\ S. GIANNETTO (4), C. MOROLLI (1), G. MINELLI (1)
}

(1) Centro di Ricerca Interdipartimentale sulle Tecnologie e l'Igiene degli Allevamenti Intensivi delle Piccole Specie, University of Bologna, Via San Giacomo 9, 40126, BOLOGNA, Italy. E-mail : fquaglio@alma.unibo.it

(2) Institute of Zoology and Limnology, University of Innsbruck, Technikerstrasse 25, 6020, INNSBRUCK, Austria.

(3) Dipartimento di Sanità Pubblica Veterinaria e Patologia Animale, University of Bologna, Via Tolara di Sopra 50, 40064, OZZANO EMILIA (BO), Italy.

(4) Dipartimento di Patologia, Malattie Infettive e Parassitarie e Ispezione degli Alimenti di Origine Animale, University of Messina, Via S. Cecilia 30, 98123, MESSINA, Italy.

\begin{abstract}
Twenty-eight freshwater crayfish were collected from 8 streams and one small lake in the province of South Tyrol (North Italy) from autumn 1999 to spring 2001, in order to investigate the presence of branchiobdellidans. At 6 of the streams the white clawed crayfish (Austropotamobius pallipes italicus) was collected, while the noble crayfish (Astacus astacus), the exotic species: signal crayfish (Pacifastacus leniusculus) and spiny-cheek crayfish (Orconectes limosus) were respectively caught at the other 2 streams and at the lake. Except for $O$. limosus, branchiobdellidans were observed on all crayfish examined. On noble crayfish, specimens of Branchiobdella italica and Branchiobdella hexodonta were found on the same host. Branchiobdella italica was largely recovered from all white clawed crayfish. The specimens of signal crayfish were found to carry only Xironogiton victoriensis.
\end{abstract}

Key-words : Branchiobdellidae, freshwater crayfish, annelids, North Italy. 


\title{
LES ESPÈCES DE BRANCHIOBDELLIDAE (ANNELIDA) OBSERVÉES SUR LES ÉCREVISSES DANS LE SUD TYROL (ITALIE DU NORD).
}

\begin{abstract}
RÉSUMÉ
A partir de l'automne 1999 jusqu'au printemps 2001 en Tyrol du Sud, 28 écrevisses ont été prélevées dans 8 ruisseaux et un petit lac dans le but de vérifier la présence des Branchiobdellidae. L'écrevisse à pieds blancs (Austropotamobius pallipes italicus) a été trouvée dans 6 ruisseaux, l'écrevisse à pieds rouges (Astacus astacus) et l'écrevisse de Californie (Pacifastacus leniusculus) dans deux ruisseaux et l'écrevisse américaine (Orconectes limosus) dans le lac. A l'exclusion de l'écrevisse américaine, on a trouvé chez toutes les autres espèces des Branchiobdellidae. Chez l'écrevisse à pieds rouges, Branchiobdella italica et Branchiobdella hexodonta sont présentes. Chez toutes les écrevisses à pieds blancs, on a relevé une grande quantité de $B$. italica alors que chez les écrevisses de Californie on a retrouvé seulement le Xironogiton victoriensis.
\end{abstract}

Mots-clés : Branchiobdellidae, écrevisse, Annelida, Italie du Nord.

\section{INTRODUCTION}

In the Italian province of South Tyrol (Northern Italy), four species of freshwater crayfish occur: the autochthonous white clawed crayfish Austropotamobius pallipes (Lereboullet, 1858) and noble crayfish Astacus astacus (Linnaeus, 1758) and the two exotic species: the signal crayfish Pacifastacus leniusculus (Dana, 1852) and spiny-cheek or striped crayfish Orconectes limosus (Rafinesque, 1817). At present, $A$. pallipes is scarcely distributed in the water bodies of South Tyrol and $A$. astacus has only been found in a single stream.

The aim of this investigation was to identify the species of branchiobdellidans isolated on the crayfish. So far Branchiobdella italica, Branchiobdella parasita, Branchiobdella hexodonta and Branchiobdella astaci were the only branchiobdellidan species reported on $A$. pallipes in North Italy and $B$. italica is the prevalent species (GELDER et al., 1994; NOBILE et al., 1995). Moreover, in this research we investigated the possibility of branchiobdellidan shifting from the autochthonous and European species $A$. pallipes and $A$. astacus to the allochthonous $P$. leniusculus populations (and viceversa) in the Ahr drainage.

\section{MATERIAL AND METHODS}

The research was carried out in September 1999 and from February to June 2001. In September 1999, 15 individuals of $P$. leniusculus were collected, while 9 A. pallipes, 2 O. limosus and a single $A$. astacus were caught from February to June 2001. The crayfish were caught with baited traps and by hand at nine different sites (Figure 1): A. pallipes from Moosbachl (Bruneck / St.Georgen), Giessbach (Staben), Hyppolithbach (Naraun), Krebsbach (Kaltern), Krebusbach (Fennberg) and Angelbach (Montiggl); A. astacus from Wiesenbach (Gais); O. limosus from Vahrn lake (Vahrn); P. leniusculus from Auenbachl (Bruneck). The crayfish were transported to laboratory during an approximately 5 hours trip. The specimens were emersed in a 1:1 solution of deionized water and carbonated bottled 
water for two minutes. The immobilized branchiobdellidans were removed from the crayfish and placed in stream water to recover, according the Gelder method (GELDER et al., 1994). The worms were examined alive under the microscope, fixed in $70 \%$ ethanol and then counted and clarified with lactophenol. The branchiobdellidans from $P$. leniusculus were stained with Borax Carmine and mounted with Glycerine Jelly or Hoyer's fluid. All the branchiobdellidans were examined and measured at the optical microscope with the aid of a " camera lucida ». The identification of the species was obtained on the basis of the jaws, the spermatheca and the spermatecal duct morphology using Gelder's identification key (GELDER and HALL, 1990; GELDER et al., 1994).

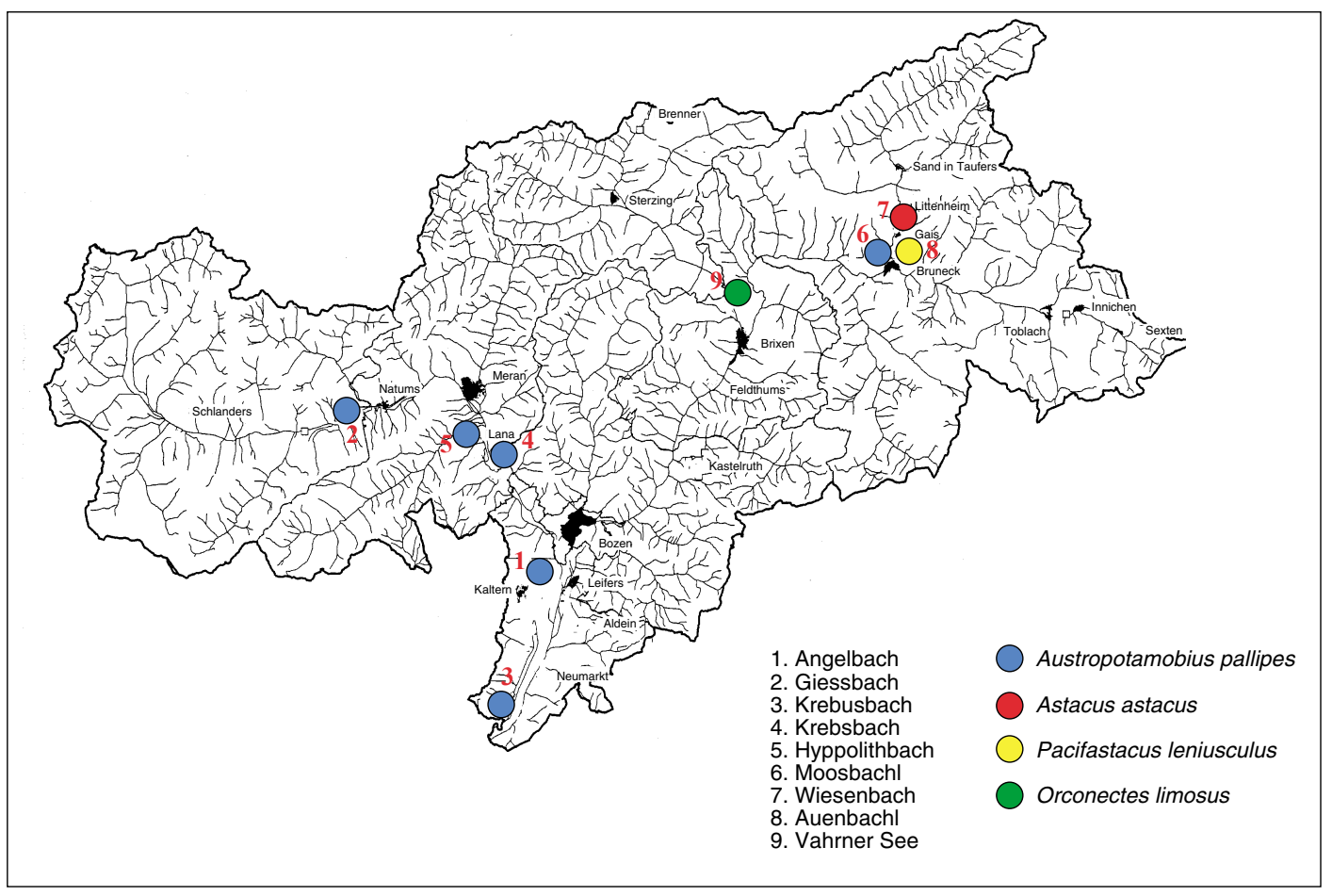

Figure 1

Sites of sampling in South Tyrol.

Figure 1

Lieux d'échantillonnage en Tyrol du Sud.

\section{RESULTS AND DISCUSSION}

On the exoskeleton of all crayfish caught, from 23 up to 2107 of branchiobdellidans / host were found, except the spiny-cheek crayfish from Vahrn lake which did not carry any of these organisms.

Branchiobdella italica (Figures 2-5) was the most widespread species, found on each individual of $A$. pallipes and $A$. astacus. The exotic species Xironogiton victoriensis (Figures 6-9) was collected only on P. leniusculus. Branchiobdella hexodonta (Figures 10-11) was observed on $A$. astacus. 
Morphological characteristics, number of counted annelids / host, specimens studied and sites sampled are showed in Table I. The dental formulas of the examined annelids are shown in Table II. On the surface of $B$. italica peritricha protozoans of the genus Epistylis (Figures 12-13) were often found. The presence of these ciliates has already been reported on crayfish populations as ectoparasites or ectocommensals (BROWN et al., 1993; SCOTT and THUNE, 1986).

\section{Table I}

Number of branchiobdellidans / host, number of branchiobdellidans examined, morphometric characteristics and sites sampled in South Tyrol.

\section{Tableau I}

Nombre de branchiobdellidae / hôte, nombre de branchiobdellidae examinées, caractéristiques morphologiques et lieux d'échantillonnage en Tyrol du Sud.

\begin{tabular}{|c|c|c|c|c|c|c|}
\hline crayfish examined & origin & $\begin{array}{c}\text { number of } \\
\text { branchiobdellidans / } \\
\text { host }\end{array}$ & $\begin{array}{c}\text { number of } \\
\text { branchiobdellidans } \\
\text { examined } \\
\end{array}$ & $\begin{array}{c}\text { species of } \\
\text { branchiobdellidan } \\
\text { found on crayfish }\end{array}$ & bodylength & bodyweight \\
\hline A. pallipes (1) & Angelbach & 80 & 31 & B. italica & 2.01 & 0.65 \\
\hline A. pallipes (1) & Giessbach & 960 & 60 & B. italica & 2.02 & 0.68 \\
\hline $\begin{array}{l}\text { A. pallipes (1) } \\
\text { A. pallipes (1) }\end{array}$ & $\begin{array}{l}\text { Krebusbach } \\
\text { Krebusbach }\end{array}$ & $\begin{array}{l}23 \\
73\end{array}$ & $\begin{array}{l}20 \\
34\end{array}$ & $\begin{array}{l}\text { B. italica } \\
\text { B. italica }\end{array}$ & $\begin{array}{l}2.53 \\
2.72\end{array}$ & $\begin{array}{l}0.75 \\
0.72\end{array}$ \\
\hline A. pallipes (1) & Krebsbach & 90 & 56 & B. italica & 3.43 & 0.83 \\
\hline $\begin{array}{l}\text { A. pallipes (1) } \\
\text { A. pallipes (1) }\end{array}$ & $\begin{array}{l}\text { Hyppolithbach } \\
\text { Hyppolithbach }\end{array}$ & $\begin{array}{l}131 \\
209\end{array}$ & $\begin{array}{c}66 \\
110\end{array}$ & $\begin{array}{l}\text { B. italica } \\
\text { B. italica }\end{array}$ & $\begin{array}{l}3.01 \\
3.09\end{array}$ & $\begin{array}{l}0.75 \\
0.72\end{array}$ \\
\hline $\begin{array}{l}\text { A. pallipes (1) } \\
\text { A. pallipes (1) }\end{array}$ & $\begin{array}{l}\text { Moosbachl } \\
\text { Moosbachl }\end{array}$ & $\begin{array}{c}262 \\
1150\end{array}$ & $\begin{array}{c}80 \\
100\end{array}$ & $\begin{array}{l}\text { B. italica } \\
\text { B. italica }\end{array}$ & $\begin{array}{l}2.56 \\
2.51\end{array}$ & $\begin{array}{l}0.67 \\
0.63\end{array}$ \\
\hline A. astacus (1) & Wiesenbach & 2107 & $\begin{array}{c}150 / 154 \\
4 / 154\end{array}$ & $\begin{array}{c}\text { B. italica } \\
\text { B. hexodonta }\end{array}$ & $\begin{array}{l}3.17 \\
3.47\end{array}$ & $\begin{array}{l}0.77 \\
0.62\end{array}$ \\
\hline$P$. leniusculus (15) & Auenbachl & 1500 (average) & 350 & $X$. victoriensis & 2.16 & 0.75 \\
\hline O. limosus (2) & Vahrner See & 0 & 0 & 1 & I & I \\
\hline
\end{tabular}

\section{Table II}

Species of branchiobdellidans collected on freshwater crayfish of South Tyrol, their dental formulas and percentage of finding.

\section{Tableau II}

Les différentes formules dentaires de Branchiobdellidae du Sud Tyrol et leurs fréquences selon les lieux de capture des écrevisses.

\begin{tabular}{lccccccc}
\hline Branchiobdellidan & \multicolumn{7}{c}{ Dental formulas and percentage of finding } \\
\hline & $6 / 5$ & $5 / 5$ & $6 / 6$ & $7 / 6$ & $7 / 5$ & $5 / 4$ & $4 / 4$ \\
& $54.84 \%$ & $41.93 \%$ & $3.22 \%$ & $/$ & $/$ & $/$ & $/$ \\
B. italica (from Angelbach) & $40.00 \%$ & $60.00 \%$ & $/$ & $/$ & $/$ & $/$ & $/$ \\
B. italica (from Giessbach) & $61.69 \%$ & $20.78 \%$ & $11.69 \%$ & $3.89 \%$ & $1.95 \%$ & $/$ & $/$ \\
B. italica (from Wiesenbach) & $61.40 \%$ & $31.58 \%$ & $3.51 \%$ & $1.75 \%$ & $1.75 \%$ & $/$ & $/$ \\
B. italica (from Krebusbach) & $47.27 \%$ & $45.45 \%$ & $7.27 \%$ & $/$ & $/$ & $/$ & $/$ \\
B. italica (from Krebsbach) & $53.97 \%$ & $44.32 \%$ & $0.57 \%$ & $/$ & $0.57 \%$ & $0.57 \%$ & $/$ \\
B. italica (from Hyppolithbach) & $53.33 \%$ & $45.00 \%$ & $0.55 \%$ & $/$ & $/$ & $1.11 \%$ & $/$ \\
B. italica (from Moosbachl) & 1 & $20.00 \%$ & $/$ & $/$ & $/$ & $37.50 \%$ & $42.50 \%$ \\
B. hexodonta (from Wiesenbach) & $100.00 \%$ & $/$ & $/$ & $/$ & $/$ & $/$ \\
X. victoriensis (from Auenbachl) & $/$ & & & $/$ & & $/$ \\
\hline
\end{tabular}




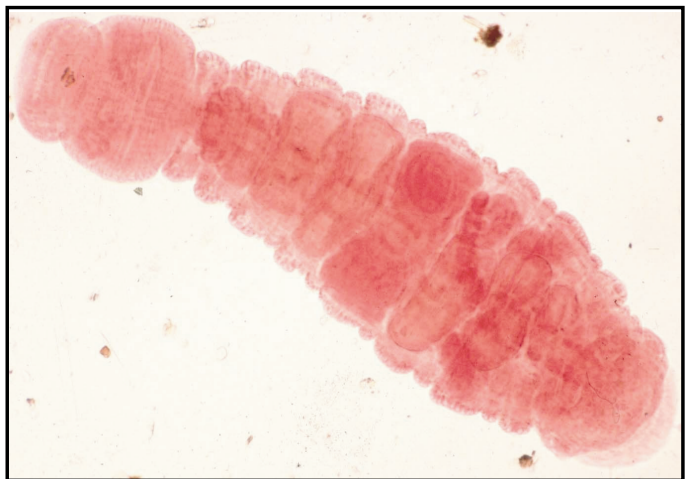

Figure 2

A fixed whole borax carmine mount of Branchiobdella italica.

Figure 2

Branchiobdella italica fixée avec le colorant borax carminé.

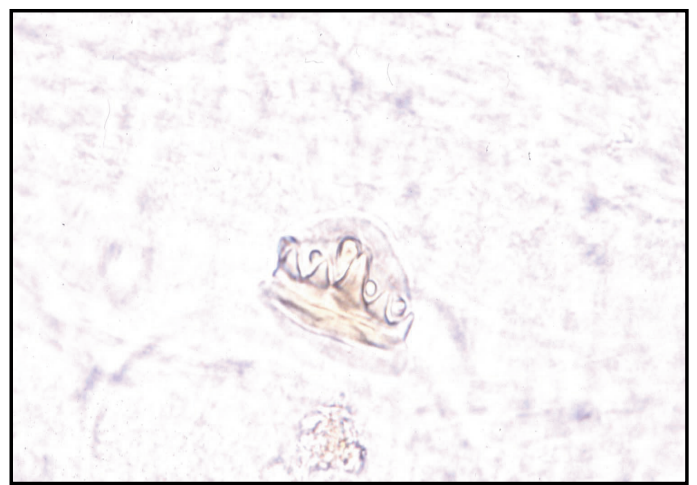

Figure 4

Branchiobdella italica: jaw with $5 / 5$ teeth (lactophenol).

Figure 4

Branchiobdella italica : mâchoire avec 5/5 dents (lactophenol).

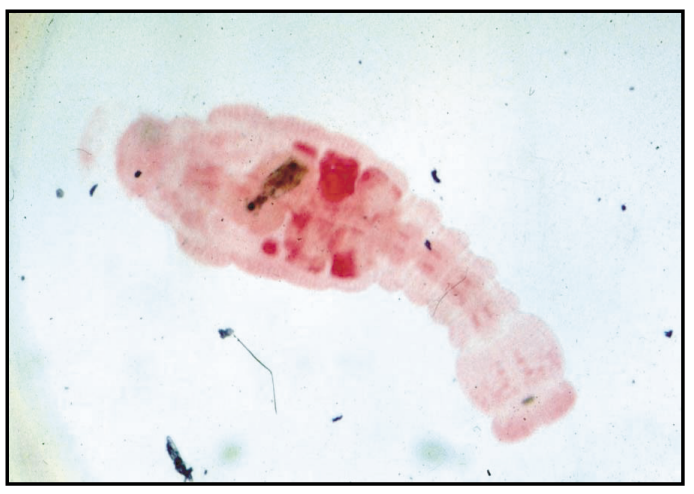

Figure 6

A fixed whole borax carmine mount of Xironogiton victoriensis.

Figure 6

Xironogiton victoriensis fixé avec le colorant borax carminé.

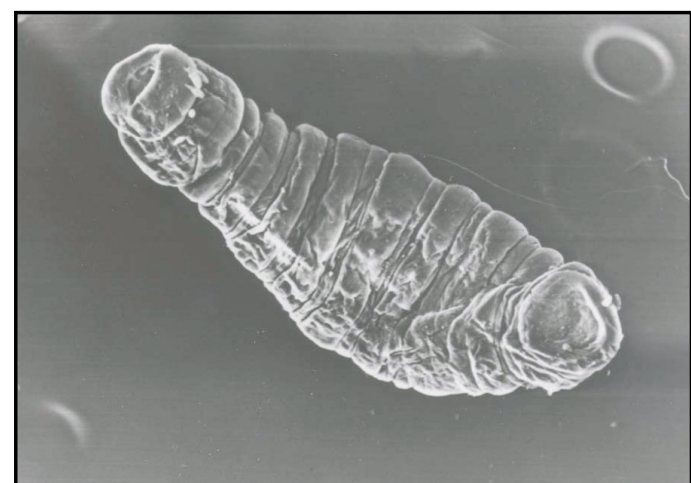

Figure 3

Ventral view of Branchiobdella italica observed with the Scanning Electron Microscope (SEM).

Figure 3

Vue ventrale de Branchiobdella italica au moyen d'un microscope électronique (SEM).

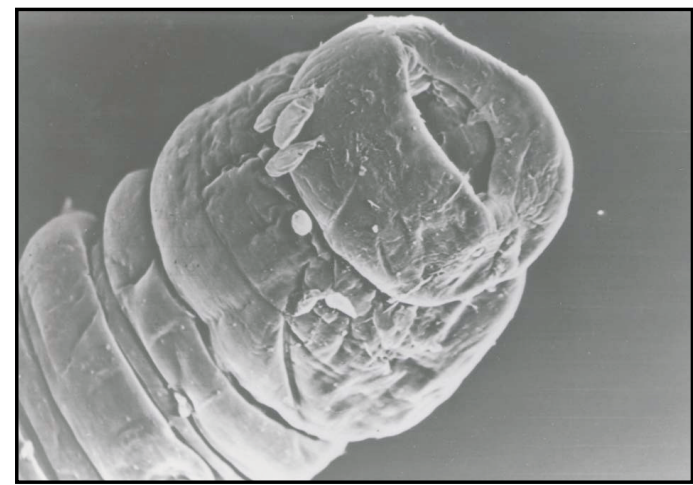

\section{Figure 5}

Branchiobdella italica: cephalic portion with oral papillae (SEM). Epistylis sp. on the cutaneous surface.

\section{Figure 5}

Branchiobdella italica : partie céphalique avec papilles orales (SEM). Epistylis sp. sur la surface cutanée.

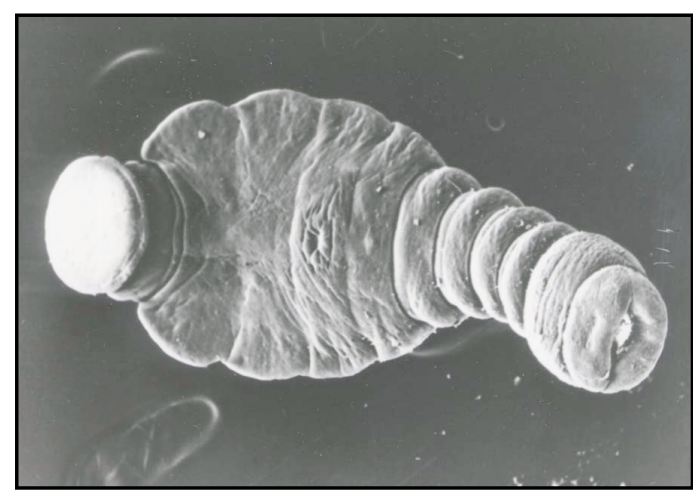

Figure 7

Ventral view of Xironogiton victoriensis observed with an Scanning Electron Microscope (SEM).

Figure 7

Vue ventrale de Xironogiton victoriensis au moyen d'un microscope électronique (SEM). 


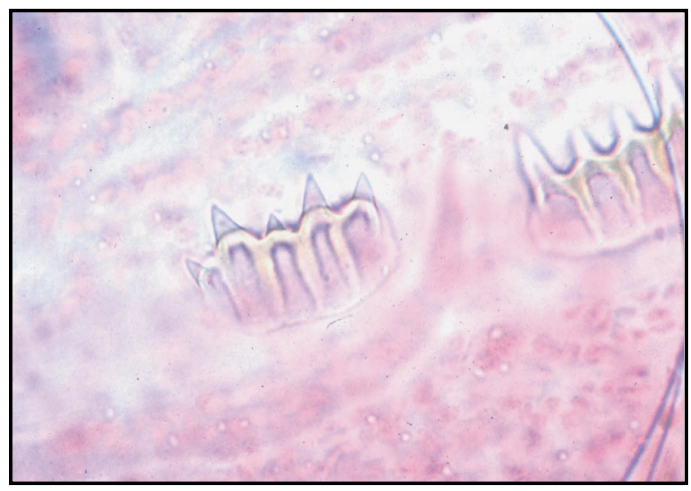

Figure 8

Xironogiton victoriensis: jaws with 5 and 4 teeth (Borax carmine).

Figure 8

Xironogiton victoriensis : mâchoire avec 5 et 4 dents (Borax carminé).

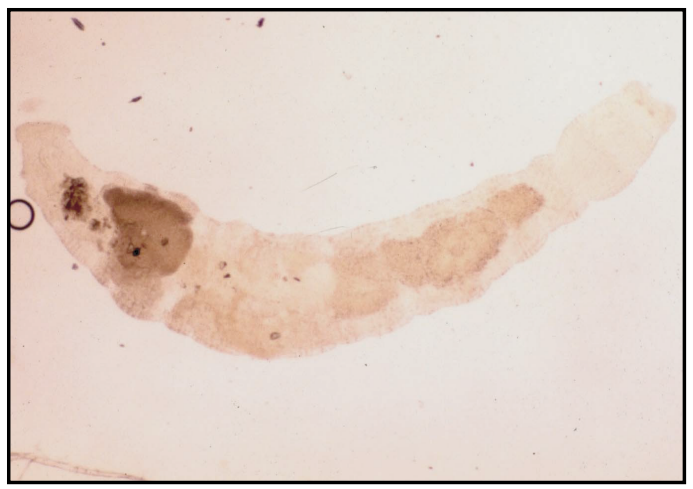

Figure 10

Branchiobdella hexodonta (lactophenol).

Figure 10

Branchiobdella hexodonta (lactophenol).

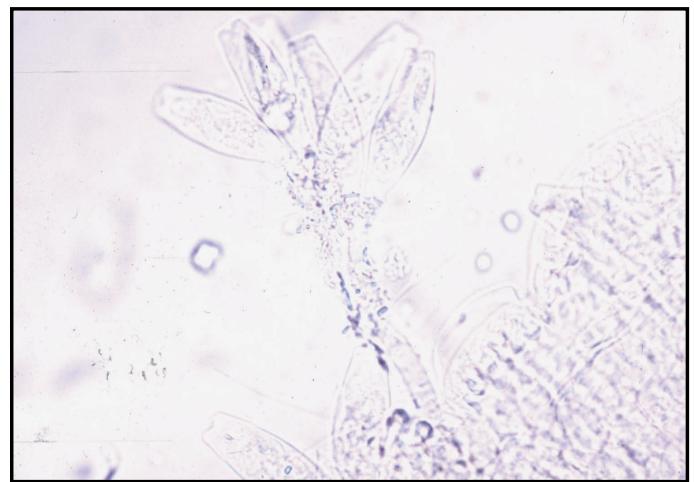

Figure 12

Epistylis sp., peritrichous, ciliated protozoan on the cutaneous surface of $B$. italica (lactophenol).

Figure 12

Epistylis sp., protozoaires ciliés, Péritriches sessiles, sur la surface cutanée de $B$. italica (lactophenol).

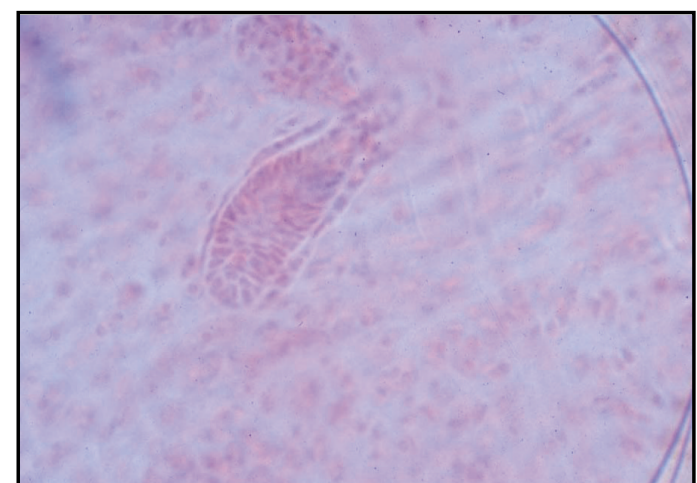

Figure 9

Xironogiton victoriensis: spermatheca (Borax carmine).

Figure 9

Xironogiton victoriensis : spermathèque (Borax carminé).

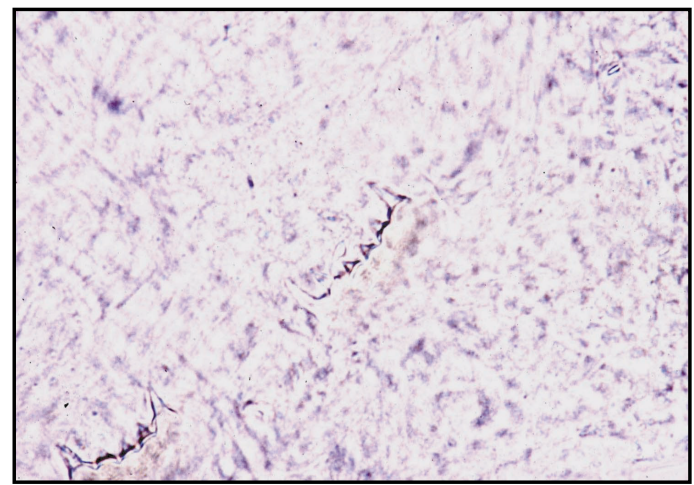

Figure 11

Branchiobdella hexodonta: jaw with $6 / 5$ teeth (lactophenol).

Figure 11

Branchiobdella hexodonta: mâchoire avec $6 / 5$ dents (lactophenol).

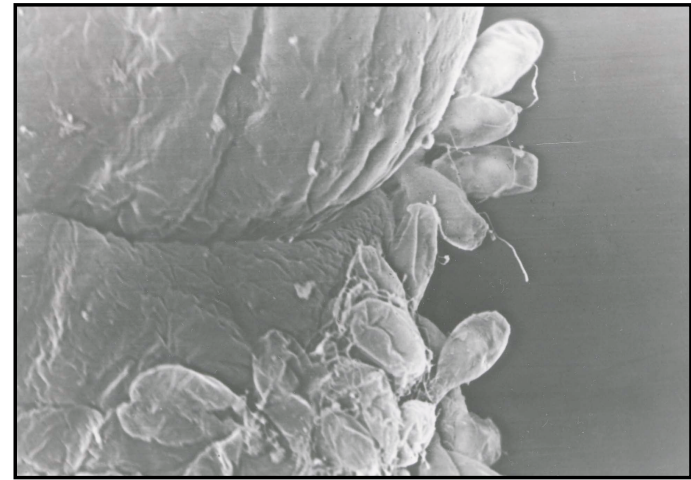

Figure 13

Epistylis sp., peritrichous, ciliated protozoan on the cutaneous surface of $B$. italica (SEM).

\section{Figure 13}

Epistylis sp., protozoaires ciliés, Péritriches sessiles, sur la surface cutanée de B. italica (SEM). 
The relationship between branchiobdellidans and their hosts is still poorly known. The worms have been variously described as diatom feeders, blood feeders or as parasites only in the adult stage. It is believed that most species are commensals or perhaps facultative parasites (BISHOP, 1968). GRABDA and WIERZBICKA (1969) provided the only experimental evidence of parasitism in affirming that $B$. hexodonta was living permanently in the branchial cavity of its host. The authors observed tissues of the crayfish in the intestinal tract of $B$. hexodonta by the use of radio-labelled markers. In a recent paper, according to GELDER (1999), branchiobdellidans are defined as ectosymbionts and not parasites. In our investigation, rotifers and chironomids were identified in the intestinal tract of some of $B$. italica. Moreover detritus of unknown nature and origin has been found to occur in different amounts.

YOUNG (1966) has studied the colonization behaviour of these annelids. He found that body contact seems to be essential to their transfer from one host to another. GRABDA and WIERZBICKA (1969) considered this behaviour to be more important in some species than in others. Some signal crayfish samples were collected by GRABER (personal communication) in the Moosbachl, where also a white clawed crayfish population lives. However we did not find on $A$. pallipes any $X$. victoriensis, which was associated with $P$. leniusculus. Either competition between the branchiobdellida species or the incompatibility to colonize of one species might be a possible explanation. GELDER (1999) assumed that a preference in the associations was determined only by branchiobdellidans. It is generally believed that the host is unable to affect or prevent the branchiobdellidans colonization. Although some species of crayfish have been observed scraping their exoskeleton and « combing » their gills with appropriate appendages (GELDER, 1999). In a laboratory tank we have observed a signal crayfish eating $X$. victoriensis from its exuviae. Another possible explanation for the lack of $X$. victoriensis on $A$. pallipes could be the low density of $P$. leniusculus in the Moosbachl. No certain explanation can be given so far. In addition, the capture of the signal crayfish from the Moosbachl is important to understand if it can be an acceptable host for the native branchiobdellidan, $B$. italica.

Quite often, two or more species of branchiobdellidans are found sympatrically on the same hosts. The noble crayfish from Wiesenbach showed to be highly populated by B. italica $(96.76 \%)$ and by some $B$. hexodonta $(3.24 \%)$. The high number of $B$. italica in comparison with the low presence of $B$. hexodonta allow to consider the possibility of a competition between the two species. Other authors didn't observe this competition. In contrast, during his research carried out in the Bergamo area (Northern Italy), GELDER et al. (1994) found more specimens of $B$. hexodonta than of $B$. italica on the same host. In our investigation, $B$. italica from Wiesenbach was bigger compared to $B$. italica found in other streams in South Tyrol. The high number and the size of $B$. italica could be influenced by physical, chemical and biological factors (MORI et al., 2000). The temperature, for example, was $7^{\circ} \mathrm{C}$ higher than in the other streams. Warmer condition could influence the growth and the colonisation of $B$. italica. Furthermore, high presence of $B$. italica can cause problems of competition and coexistence of other species with similar life styles.

Our investigations provided some interesting and new findings about the occurrence of branchiobdella and their hosts. However more studies are needed to confirm these observations and to obtain more accurate data.

\section{REFERENCES}

BISHOP J.E., 1968. An ecological study of the branchiobdellid commensals (AnnelidaBranchiobdellidae) of some mid-western Ontario crayfish. Canadian Journal of Zoology, 46, 835-843.

BROWN P.B., WHITE R.M., SWANN L.D., FULLER M.S., 1993. A severe outbreak of ectoparasitism due to Epistylis sp. in pond-reared orconectid crayfish. Journal of the World Aquaculture Society, 24 (1), 116-120. 
GELDER S.R., 1999. Zoogeography of branchiobdellidans (Annelida) and temnocephalidans (Platyhelminthes) ectosymbiotic on freshwater crustaceans, and their reactions to one another in vitro. Hydrobiologia, 406, 21-31.

GELDER S.R., HALL L.A., 1990. Description of Xironogiton victoriensis n. sp. from British Columbia, Canada, with remarks on other species and a Wagner analysis of Xironogiton (Clitellata: Branchiobdellida). Canadian Journal of Zoology, 68, 2352-2359.

GELDER S.R., DELMASTRO G.B., FERRAGUTI M., 1994. A report on branchiobdellidans (Annelida: Clitellata) and a taxonomic key to the species in northern Italy, including the first record of Cambarincola mesochoreus on the introduced American red swamp crayfish. Boll. Zool., 61, 179-183.

GRABDA E., WIERZBICKA J., 1969. The problems of parasitism of the species of the genus Branchiobdella Odier, 1823. Polskie Archiwum Hydrobiologii, 16 (29), 93-104.

MORI M., ROSSO E., SALVIDIO S., 2000. Presenza e incidenza delle branchiobdelle (Anneldia, Branchiobdellidae) nelle populazioni astacicole liguri. Estratto dagli Annali del Museo Civico di Storia Naturale «G. Doria », Vol XCIII, Genova, 21. Febbraio 2000, 211-224.

NOBILE L., GIANNETTO S., TRENTINI M., CANESTI TROTTI G., RESTANI R., 1995. Indagine sulla diffusione di Branchiobdella spp. (Annelida, Branchiobdellidae) in gamberi d'acqua dolce (Austropotamobius pallipes italicus) dell'Appennino ToscoEmiliano. Bollettino della Società Italiana di Patologia Ittica, 16, 26-33.

SCOTT J.R., THUNE R.L., 1986. Ectocommensal protozoan infestations of gills of red swamp crayfish, Procambarus clarkii (Girard), from commercial ponds. Aquaculture, 55, 161-164.

YOUNG W., 1966. Ecologial studies of the Branchiobdellidae (Oligochaeta). Ecology, 47 (4), 571-578. 